Received: 10 July 2017

Accepted: 20 September 2017

Published online: 11 October 2017

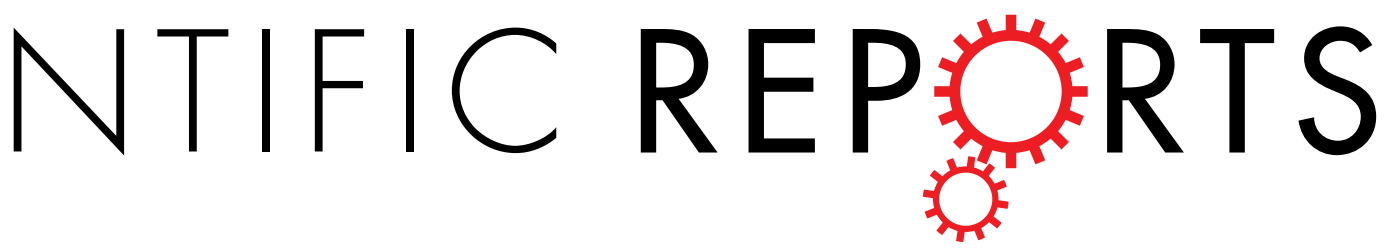

\title{
A turn-on endoplasmic reticulum- targeted two-photon fluorescent probe for hydrogen sulfide and bio- imaging applications in living cells, tissues, and zebrafish
}

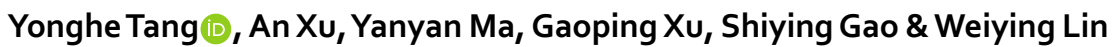

As one of the important gas signal molecules, hydrogen sulfide $\left(\mathrm{H}_{2} \mathrm{~S}\right)$ is associated with many important physiological processes in living organisms. Organelles, especially endoplasmic reticulum (ER), play a crucial role in the cell metabolism. Accordingly, the detection of $\mathrm{H}_{2} \mathrm{~S}$ in the ER is of high interest. Toward this goal, we have described the development of the first ER-targeted fluorescent $\mathrm{H}_{2} \mathrm{~S}$ probe (Na-

$\mathrm{H}_{2} \mathrm{~S}$-ER). The new probe exhibited favorable features, such as a large turn-on fluorescence signal (45fold fluorescence enhancement), high sensitivity and selectivity. The probe was successfully employed for imaging exogenous and endogenous $\mathrm{H}_{2} \mathrm{~S}$ in the living HeLa cells. Significantly, the new probe $\mathrm{Na}$ $\mathrm{H}_{2} \mathrm{~S}$-ER was employed to visualize $\mathrm{H}_{2} \mathrm{~S}$ in the ER of living cells for the first time. In addition, the probe was also successfully used for imaging $\mathrm{H}_{2} \mathrm{~S}$ in the living tissues up to a depth of $100 \mu \mathrm{m}$ and in the living zebrafish.

Although hydrogen sulfide $\left(\mathrm{H}_{2} \mathrm{~S}\right)$ is an important industrial raw material in the sulfide industry, it is also a serious hazardous substance in the industrial process. For example, $\mathrm{H}_{2} \mathrm{~S}$ could seriously corrode metallic equipment ${ }^{1}$. Early researches suggest that $\mathrm{H}_{2} \mathrm{~S}$ has been regarded as a poisonous and harmful gas ${ }^{2}$. Prolonged exposure to $\mathrm{H}_{2} \mathrm{~S}$ may lead to a series of malignant diseases, such as Down syndrome ${ }^{3}$, Alzheimer's disease ${ }^{4}$, diabetes ${ }^{5}$, and liver cirrhosis ${ }^{6}$. However, recent studies show that $\mathrm{H}_{2} \mathrm{~S}$ is also a gas signal molecule and plays the important physiological functions as the same as nitric oxide (NO) and carbon monoxide (CO) in organisms ${ }^{7,8}$. Endogenous $\mathrm{H}_{2} \mathrm{~S}$ is involved in many physiological activities including regulating cardiovascular systems, influencing the proliferation and apoptosis of human cells, stabilizing the nervous and the immune system. Medical researches show that endogenous $\mathrm{H}_{2} \mathrm{~S}$ is produced from $\mathrm{L}$-cysteine by the enzyme-catalytic reaction of cystathionine- $\gamma$-lyase (CSE), cystathionine- $\beta$-synthetase (CBS), and 3-mercaptopyruvate sulfurtransferase (3-MST) ${ }^{9-11}$. Although $\mathrm{H}_{2} \mathrm{~S}$ is associated with different physiological processes, most of the physiological functions of $\mathrm{H}_{2} \mathrm{~S}$ are still unknown. Therefore, the development of detection methods for $\mathrm{H}_{2} \mathrm{~S}$ with high sensitivity and good selectivity is very valuable in complicated biological systems.

Nowadays, there are some analytical methods for $\mathrm{H}_{2} \mathrm{~S}$ including colorimetry ${ }^{12}$, electrochemical assay ${ }^{13}$, gas chromatography ${ }^{14}$, and sulfide precipitation ${ }^{15}$. However, these techniques can't realize the instantaneous monitoring of $\mathrm{H}_{2} \mathrm{~S}$. In addition, the tissues or cells samples need to be destroyed in the detection process. By comparison, the fluorescence imaging methods have many advantages, such as high selectivity and sensitivity, and undamaged samples in the detection process ${ }^{16-19}$. In fluorescence imaging, the two-photon fluorescence imaging has drawn much attention because of low photo-damage sample, deep penetration, and low background fluorescence ${ }^{20-22}$.

In the eukaryotic cells, the endoplasmic reticulum (ER) is the largest organelle with single-membrane structure $^{23}$. The ER performs a variety of functions in living cells, including synthesizing, processing, and modifying protein and lipid, stabilizing intracellular $\mathrm{Ca}^{2+}$ concentrations ${ }^{24}$. Biologist studies show that the ER is closely associated with other organelles, including golgi apparatus, cell membrane, and mitochondria ${ }^{25-27}$. So far, many

Institute of Fluorescent Probes for Biological Imaging, School of Chemistry and Chemical Engineering, School of Materials Science and Engineering, University of Jinan, Jinan, Shandong, 250022, P.R. China. Correspondence and requests for materials should be addressed toW.L. (email: weiyinglin2013@163.com) 
ER-Targetable moiety<smiles>Cc1ccc(S(=O)(=O)NCCN2C(=O)C3=CC=Cc4c([N]C(=O)O)cc(CC(C)(C)C)c3c4C2=O)cc1</smiles>

$\mathrm{H}_{2} \mathrm{~S}$ recognition site<smiles>Cc1ccc(S(=O)(=O)NCCN2C(=O)c3cccc4c(N)ccc(c34)C2=O)cc1</smiles>

Na-ER

\section{Weak Fluorescence}

\section{Strong Fluorescence}

Figure 1. The structure of the probe $\mathbf{N a}-\mathbf{H}_{2} \mathrm{~S}-\mathbf{E R}$ and the proposed recognition mechanism for $\mathrm{H}_{2} \mathrm{~S}$.

fluorescent probes have been reported for $\mathrm{H}_{2} \mathrm{~S}$ detection in the past decade ${ }^{28-39}$. However, because of lack of the ER-specific fluorescent probes, the detection of physiological function of $\mathrm{H}_{2} \mathrm{~S}$ in the ER is still very challenging.

Herein, we report the first ER-targeted $\mathrm{H}_{2} \mathrm{~S}$ fluorescent probe $\mathbf{N a}-\mathrm{H}_{2} \mathbf{S}$-ER. The probe contains the fluorescent platform 1,8-naphthalimide, and the $\mathrm{H}_{2} \mathrm{~S}$ recognition site azide group. Combined with the methyl sulfonamide group, the fluorescent probe $\mathbf{N a}-\mathrm{H}_{2} \mathrm{~S}$-ER preferentially accumulated in the $\mathrm{ER}^{40-43}$. Through the spectrum analysis, the probe $\mathbf{N a}-\mathrm{H}_{2} \mathrm{~S}$-ER shows excellent selectivity and sensitivity to $\mathrm{H}_{2} \mathrm{~S}$ relative to other analytes, and the probe can be used to detect $\mathrm{H}_{2} \mathrm{~S}$ in cells. In addition, the probe $\mathbf{N a}-\mathrm{H}_{2} \mathbf{S}-\mathbf{E R}$ is suitable for fluorescence imaging of $\mathrm{H}_{2} \mathrm{~S}$ in living tissues and zebrafish.

\section{Results and Discussion}

Design and synthesis. Naphthylamide dye is a classical fluorescence platform and has excellent two-photon properties. We used naphthylamide and introduced the $\mathrm{H}_{2} \mathrm{~S}$ identification site azide group to construct a fluorescent $\mathrm{H}_{2} \mathrm{~S}$ probe, named as $\mathbf{N a - H _ { 2 }} \mathbf{S}$-ER. Attach the strong electron-withdrawing azide group to the naphthalimide fluorescent platform directly, the electronic structure of the probe was shown as "A- $\pi-A$ ". This electronic structure made the fluorescent probe have a weak fluorescent emission signal. When the probe was treated with $\mathrm{H}_{2} \mathrm{~S}$, the azide group became an amine moiety, and the electronic structure of the probe become " $D-\pi-A$ " because of the amine moiety was the strong electron-donating group. Due to the intramolecular charge transfer (ICT) effect, the fluorescent probe had strong fluorescent emission (Fig. 1). Sulfonylurea compounds are inhibitors of ATP-sensitive $\mathrm{K}^{+}$channels, and thus can selectively bind to these proteins that are prominent on ER. Therefore, fluorescent analogues of sulfonylurea are usually used to label ER. As shown in Fig. S1, glyburide was used as the targeting group in ER-tracker Green and ER-tracker Red. In contrast, in ER-tracker Blue, sulfanilamide, an analogue of sulfonylurea, was used as the recognition group. Therefore, in this work, we have also used sulfanilamide as the targeting group, and constructed the probe that can label ER due to selectively binding to ATP-sensitive $\mathrm{K}^{+}$ channels. The synthetic route of the fluorescent probe was shown in Fig. S2. The new compound Na- $\mathrm{H}_{2} \mathrm{~S}-\mathrm{ER}$ was fully characterized by ${ }^{1} \mathrm{H}$ NMR, ${ }^{13} \mathrm{C}$ NMR and HR-MS.

Optical properties of probe $\mathrm{Na}-\mathrm{H}_{2} \mathrm{~S}-\mathrm{ER}$. After synthesizing the probe, we first tested its absorption spectra with different concentration of $\mathrm{Na}_{2} \mathrm{~S}$ (acknowledged as a release reagent of $\mathrm{H}_{2} \mathrm{~S}$ ) in PBS buffer $(\mathrm{pH} 7.4,5 \%$

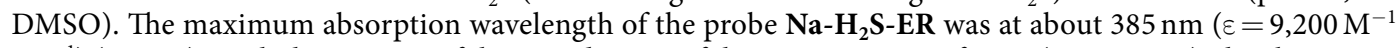
$\mathrm{cm}^{-1}$ ) (Fig. S3). With the increase of the introduction of the concentration of $\mathrm{Na}_{2} \mathrm{~S}(0-20$ equiv.), the absorption value of the probe at $385 \mathrm{~nm}$ gradually reduced, and the absorption value at $440 \mathrm{~nm}$ gradually increased. Similar to the absorption spectrum, the fluorescence emission spectrum of the probe $\mathbf{N a}-\mathbf{H}_{2} \mathbf{S}-\mathbf{E R}$ also changed significantly. As designed, the free probe was almost non-fluorescent because of the specific electronic structure of the probe. However, when titrated with $\mathrm{Na}_{2} \mathrm{~S}$, a significant fluorescence turn-on response at $545 \mathrm{~nm}$ was observed (Fig. 2). The large fluorescence enhancement (up to 45 -fold) was observed when the probe was treated with $\mathrm{Na}_{2} \mathrm{~S}$ (20 equiv.) for $30 \mathrm{~min}$ at room temperature (Fig. 2). Based on the titration experiments, the detection limit of the probe for $\mathrm{H}_{2} \mathrm{~S}$ was calculated to be $7.77 \times 10^{-6} \mathrm{M}$ (Fig. S4), indicating that the fluorescent probe has a potential application value for detecting $\mathrm{H}_{2} \mathrm{~S}$ due to it could detect the dynamic changes of $\mathrm{H}_{2} \mathrm{~S}$ concentrations in the living system.

Mechanism. The compound Na-ER (the reaction product of the probe with $\mathrm{Na}_{2} \mathrm{~S}$ ) was synthesized to further verify the design strategy of the probe $\mathbf{N a - H _ { 2 }}$ S-ER. Na-ER was purified by the column chromatography, and the 

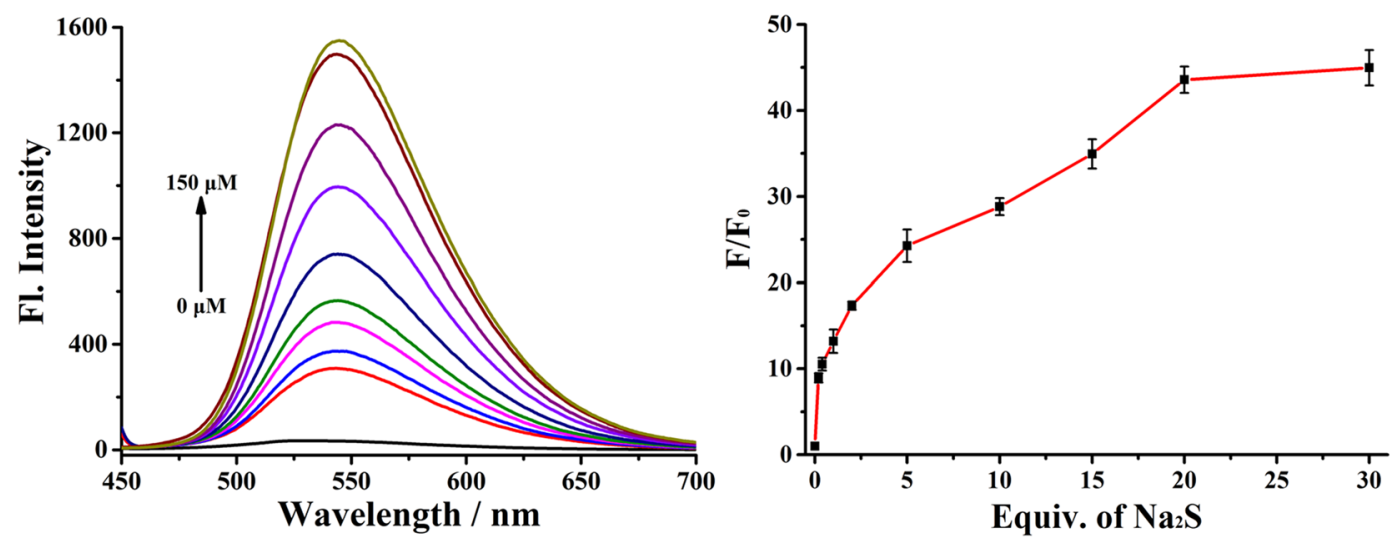

Figure 2. Fluorescence spectra of the probe $\mathrm{Na}_{2} \mathrm{H}_{2} \mathrm{~S}-\mathrm{ER}(5 \mu \mathrm{M})$ in $10 \mathrm{mM}$ PBS buffer (pH 7.4, 5\% DMSO) with various concentrations of $\mathrm{Na}_{2} \mathrm{~S}$.

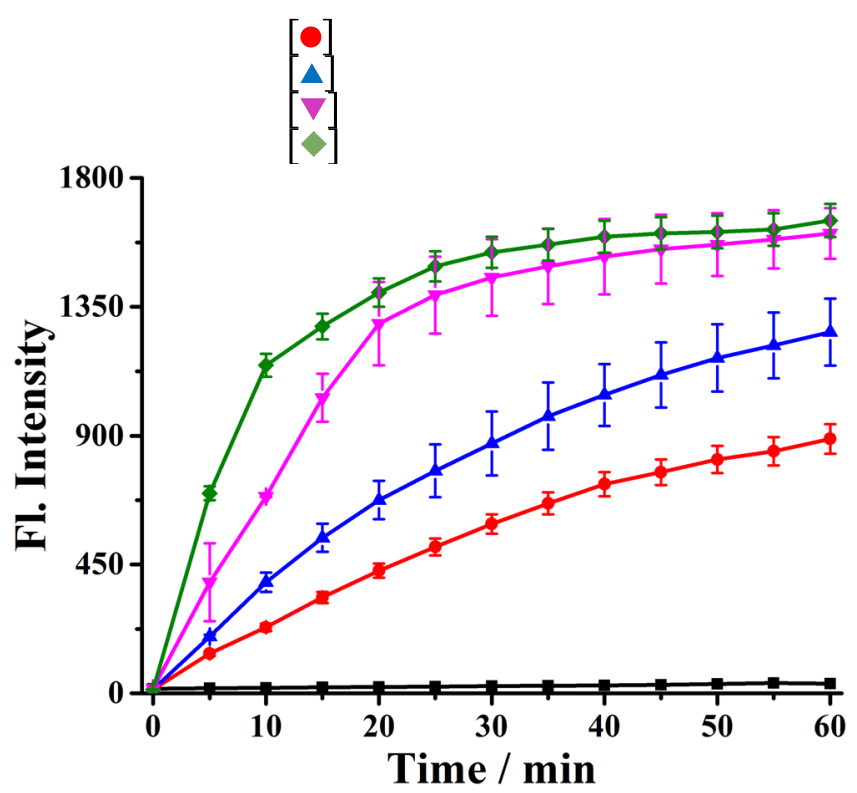

Figure 3. Reaction-time profiles of the probe $\mathrm{Na}_{2} \mathrm{H}_{2} \mathrm{~S}$-ER $(5 \mu \mathrm{M})$ in the absence [ $\mathbf{\square}$ ) or presence of $\mathrm{Na}_{2} \mathrm{~S}(10 \mu \mathrm{M}$ $[\bullet], 25 \mu \mathrm{M}[\mathbf{\Delta}], 100 \mu \mathrm{M}[\nabla]$, and $150 \mu \mathrm{M}[\bullet])$. The fluorescence intensities at $545 \mathrm{~nm}$ were continuously monitored at time intervals in PBS buffer.

structure was determined by NMR (Figs S5 and S6) analysis and HR-MS spectrometry (Fig. S7). These results confirmed that the recognition mechanism of the probe with $\mathrm{H}_{2} \mathrm{~S}$ as proposed we expected (Fig. 1).

Dynamic research. The rate of response is a basic parameter of the probe recognition capability, we then carried out the dynamic test of the probe $\mathrm{Na}-\mathrm{H}_{2} \mathrm{~S}$-ER $(5 \mu \mathrm{M})$ reacted with various concentrations of $\mathrm{Na}_{2} \mathrm{~S}$ (Fig. 3). Untreated with $\mathrm{Na}_{2} \mathrm{~S}$, the fluorescence intensity of the probe had almost no change within 60 min. By contrast, the fluorescence intensity changed significantly when the addition of $\mathrm{Na}_{2} \mathrm{~S}$. The intensity essentially reached a maximum in 30 min at room temperature when the probe $\mathbf{N a}-\mathbf{H}_{2} \mathbf{S}-\mathbf{E R}(5 \mu \mathrm{M})$ reacted with $\mathrm{Na}_{2} \mathrm{~S}(100 \mu \mathrm{M})$. Under the pseudo-first-order conditions, the rate constant for the probe was determined to be $k=0.0702 \mathrm{~min}^{-1}$ (Fig. S8), suggesting that the probe may be used to detect $\mathrm{H}_{2} \mathrm{~S}$ for real-time imaging applications in living systems.

Selectivity study. The high selectivity of probe makes it potentially useful for biomedical application. To investigate the selectivity, $\mathbf{N a - H _ { 2 }} \mathbf{S}$-ER $(5 \mu \mathrm{M})$ was treated with various relevant analytes, including various anions/cations, representative amino acid, reactive oxygen/nitrogen species (ROS/RNS) in $10 \mathrm{mM}$ PBS buffer (pH 7.4, 5\% DMSO) (Fig. 4). The addition of the anions $\left(\mathrm{Br}^{-}, \mathrm{NO}_{2}^{-}, \mathrm{Cl}^{-}, \mathrm{NO}_{3}^{-}, \mathrm{AcO}^{-}, \mathrm{F}^{-}, \mathrm{HSO}_{3}^{-}, \mathrm{SCN}^{-}, \mathrm{I}^{-}, \mathrm{S}_{2} \mathrm{O}_{3}{ }^{2-}\right.$, $\left.\mathrm{SO}_{4}{ }^{2-}\right)$ and cations $\left(\mathrm{Na}^{+}, \mathrm{K}^{+}, \mathrm{Mg}^{2+}, \mathrm{Zn}^{2+}, \mathrm{Fe}^{2+}\right)$, ROS/RNS $\left(\mathrm{H}_{2} \mathrm{O}_{2}, \mathrm{NaClO}\right.$, tert-butylhydroperoxide (TBHP), di-tert-butylperoxide (DTBP), NO), representative amino acid (glycine (Gly), alanine (Ala), cysteine (Cys), homocysteine (Hcy), glutathione (GSH)), and other analytes (Vitamin C (VC), sodium citrate) at $100 \mu \mathrm{M}$ caused almost no change of the fluorescence intensity of the probe $\mathbf{N a}-\mathbf{H}_{2} \mathrm{~S}-\mathbf{E R}$ at room temperature for $30 \mathrm{~min}$. By 


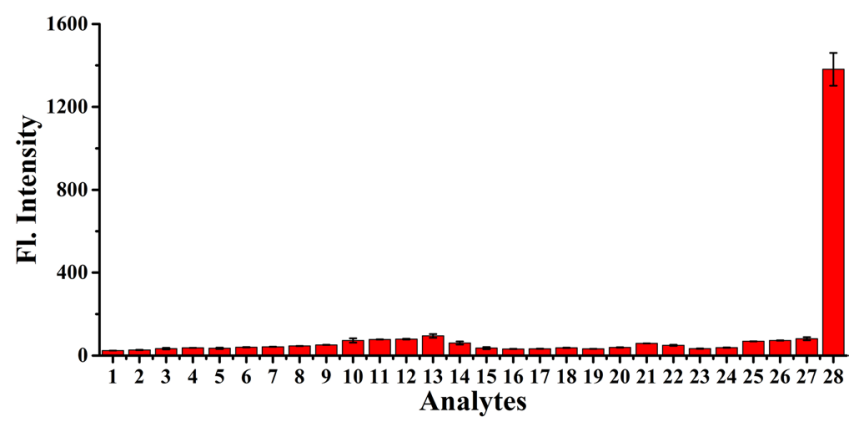

Figure 4. Fluorescence responses of $\mathbf{N a}-\mathbf{H}_{2} \mathbf{S}$-ER $(5 \mu \mathrm{M})$ in the presence of various relevant analytes in $10 \mathrm{mM}$ PBS buffer ( $\mathrm{pH} 7.4,5 \%$ DMSO). The concentrations of the representative analytes are: $100 \mu \mathrm{M}$. Legend: (1) probe; (2) $\mathrm{NaBr}$; (3) $\mathrm{NaNO}_{2}$; (4) $\mathrm{MgCl}_{2}$; (5) $\mathrm{NaNO}_{3}$; (6) $\mathrm{Zn}(\mathrm{OAc})_{2}$; (7) $\mathrm{ZnCl}_{2}$; (8) KF; (9) $\mathrm{NaHSO}_{3}$; (10) KSCN; (11) KI; (12) $\mathrm{Na}_{2} \mathrm{~S}_{2} \mathrm{O}_{3}$; (13) $\mathrm{FeSO}_{4}$; (14) $\mathrm{N}_{2} \mathrm{H}_{4}$; (15) TBHP; (16) DTBP; (17) $\mathrm{H}_{2} \mathrm{O}_{2}$; (18) NaClO; (19) NO; (20) sodium citrate; (21) glucose; (22) VC; (23) Gly; (24) Ala; (25) GSH; (26) Hcy; (27) Cys; (28) $\mathrm{Na}_{2} \mathrm{~S}$. $\lambda_{\mathrm{ex}} / \mathrm{em}=440 / 545 \mathrm{~nm}$.

contrast, upon treatment of $\mathrm{Na} 2 \mathrm{~S}(100 \mu \mathrm{M})$ with the probe, the significant change occurred in the fluorescence intensity of the probe (about 45 -fold fluorescence enhancement). These results showed that the probe has a high selectivity for $\mathrm{H}_{2} \mathrm{~S}$ over the other tested analytes, suggesting that probe had the potential to detect hydrogen sulfide in living biological systems.

The $\mathrm{pH}$ and photostability studies. The $\mathrm{pH}$ and photostability are all related to the application of the probe. We then examined the possible effects of different $\mathrm{pH}$ on the fluorescence changes of the probe $\mathrm{Na}_{2} \mathrm{H}_{2} \mathrm{~S}-\mathbf{E R}$ in the absence or presence of $\mathrm{Na}_{2} \mathrm{~S}$ (Fig. S9). The fluorescence intensity of the probe was almost unchanged over a wide $\mathrm{pH}$ range of 4-10 range in the absence of $\mathrm{Na}_{2} \mathrm{~S}$, indicating that the probe was almost impervious to the effect of $\mathrm{pH}$. However, when $\mathrm{Na}_{2} \mathrm{~S}$ was introduced, a remarkable fluorescent signal enhancement was observed at about $545 \mathrm{~nm}$, especially under the physiological conditions ( $\mathrm{pH}$ 7.4). These results suggested that the probe can detect $\mathrm{H}_{2} \mathrm{~S}$ in different $\mathrm{pH}$ environments, indicating that the probe has the potential value for biological applications. Furthermore, the photostability experiment was also carried out. After excited by the short wavelength UV light $(365 \mathrm{~nm})$, the fluorescent intensity of the probe displayed slight variation (Fig. S10), suggesting that the probe has good photostability and may have potential usefulness in living system.

Cytotoxicity and bio-imaging $\mathrm{H}_{2} \mathrm{~S}$ in living HeLa cells. As a potential imaging agent, the probe $\mathrm{Na}_{2} \mathrm{H}_{2} \mathrm{~S}-\mathrm{ER}$ should have low toxicity. We carried out a cytotoxicity test for the fluorescence probe using the standard MTT assay (Fig. S11). The results showed that the probe has no remarkable cytotoxicity to the cells in low doses $(0-20 \mu \mathrm{M})$ after $24 \mathrm{~h}$ of incubation, meaning that the probe can be used for imaging experiments.

Because the probe had many excellent properties, including high sensitivity and selectivity, good photostability, low cytotoxicity, and working appropriately at the physiological $\mathrm{pH}$, we would carry out the fluorescence imaging experiments in living cells. Because of the 1,8-naphthalimide is the classic two-photon dye, the fluorescence imaging experiments were carried out by the one-photon (OP) mode and two-photon (TP) mode. There was no fluorescent signal was detected when the HeLa cells were only incubated with probe $(5 \mu \mathrm{M})$ whether by OP or TP mode (Fig. S12b,d). By contrast, when the HeLa cells were pre-incubated with probe $(5 \mu \mathrm{M})$, and then treated with $\mathrm{Na}_{2} \mathrm{~S}(50 \mu \mathrm{M})$, a very strong fluorescent signals could be detected by OP and TP excitation (Fig. S12f,h), confirming that the fluorescence probe has good biocompatibility and it is able to recognize the exogenous $\mathrm{H}_{2} \mathrm{~S}$ in the living cells.

Encouraged by the results of the exogenous $\mathrm{H}_{2} \mathrm{~S}$ imaging experiment, we decided to investigate the ability of the fluorescent probe Na-H $\mathbf{S}$-ER to identify the endogenous $\mathrm{H}_{2} \mathrm{~S}$ in the living cells. Researches show that endogenous $\mathrm{H}_{2} \mathrm{~S}$ can be generated by the enzymatic reaction of CSE with Cysteine (Cys) in living cells ${ }^{10}$. The cells treated with probe $(5 \mu \mathrm{M})$ showed non-fluorescence signal (Fig. $5 \mathrm{~b}, \mathrm{~d})$. Under the same imaging parameters, we pre-incubated HeLa cells with Cys $(100 \mu \mathrm{M})$ and then treated the cells with probe $(5 \mu \mathrm{M})$, a dramatic fluorescent enhancement was observed by OP and TP modes (Fig. 5f,h). In order to further verify the increased fluorescent signals were mainly generated by the reaction between the probe and the endogenous $\mathrm{H}_{2} \mathrm{~S}$, we carried out a negative control imaging experiment. We conducted the negative control imaging experiment with propargylglycine (PAG) because it decreased the intracellular $\mathrm{H}_{2} \mathrm{~S}$ concentration by inhibiting the activity of CSE ${ }^{44}$. As shown in the Fig. 5j,l, with the addition of PAG $(200 \mu \mathrm{M})$, the fluorescence intensity of the probe decreased significantly whether by OP or TP mode. These data indicated that the probe $\mathbf{N a}-\mathbf{H}_{2} \mathbf{S}-\mathbf{E R}$ can monitor endogenous $\mathrm{H}_{2} \mathrm{~S}$ in living cells.

Colocalization imaging experiments. Encouraged by the above promising results of above imaging experiments, we decided to further verify the sub-cellular distribution of $\mathbf{N a}-\mathbf{H}_{2} \mathbf{S}$-ER with exogenous $\mathrm{H}_{2} \mathrm{~S}$. Because the methyl sulfonamide group is an effective targeting group for ER, the Hela cells were co-incubated with Na- $\mathrm{H}_{2} \mathrm{~S}$-ER, $\mathrm{Na}_{2} \mathrm{~S}$ and the ER-Tracker TM Red (a commercial available ER Tracker) for the colocalization study (Fig. 6). The HeLa cells showed strong fluorescent signals in the green channel $\left(\lambda_{\mathrm{ex}}=488 \mathrm{~nm}\right.$; $\left.\lambda_{\mathrm{em}}=500-550 \mathrm{~nm}\right)$ in the presence of $\mathrm{Na}_{2} \mathrm{~S}$. Meanwhile, a significant fluorescence was detected in the red channel 

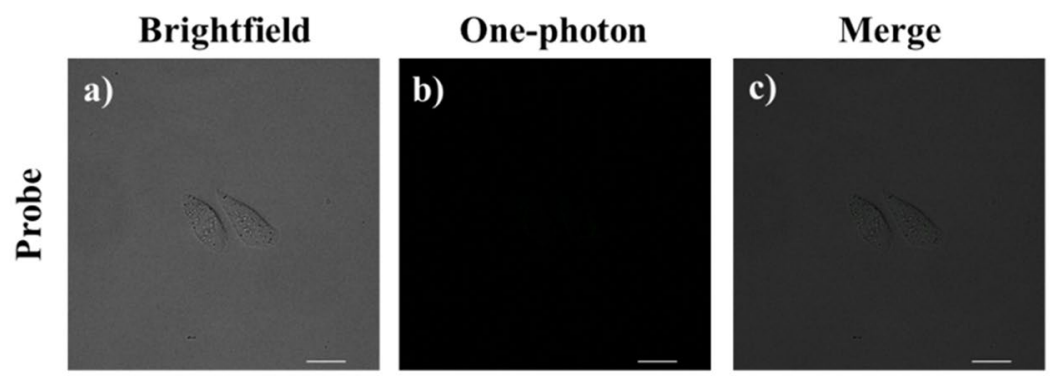

\section{Two-photon}
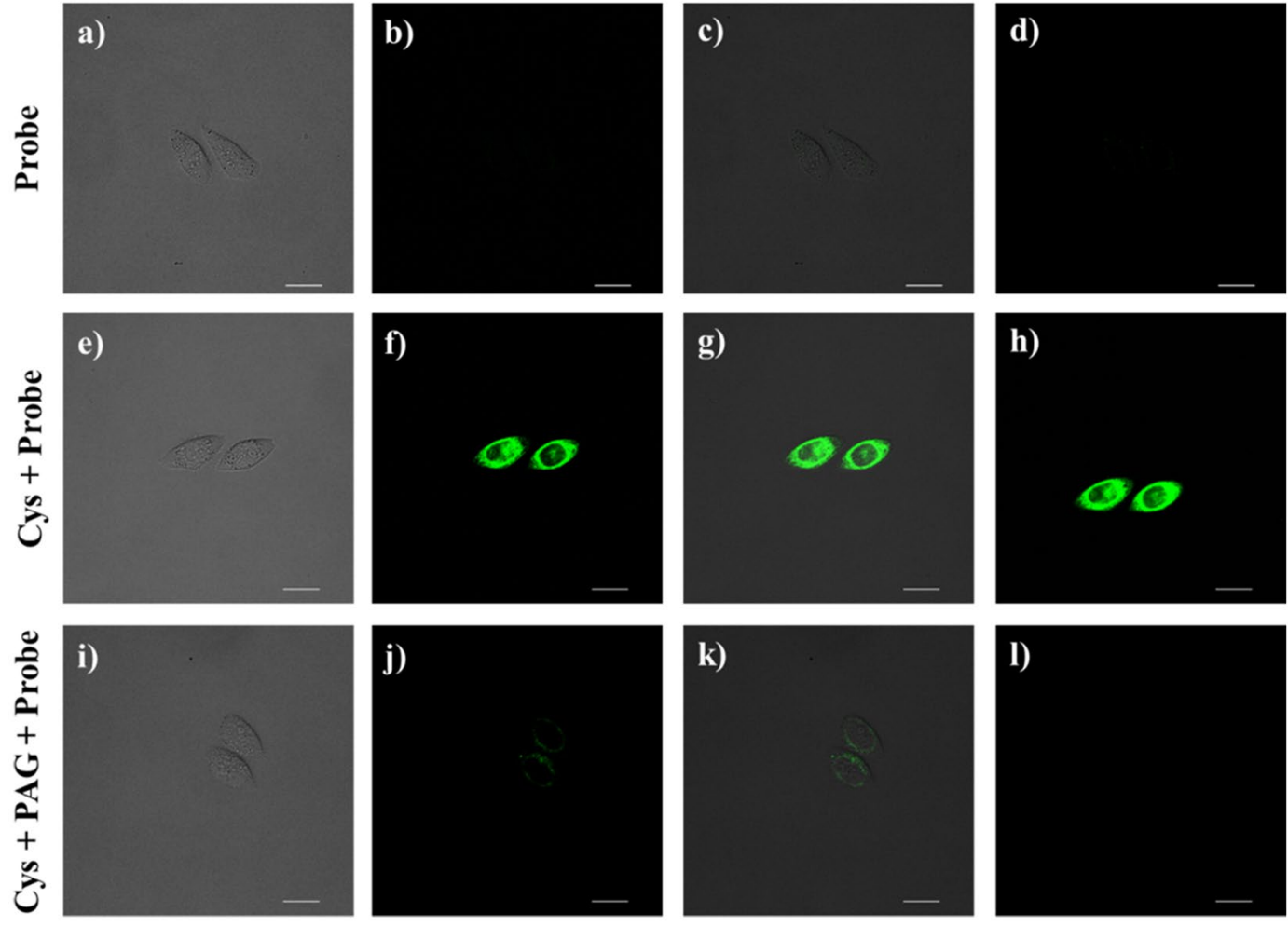

Figure 5. Fluorescence imaging of the endogenous $\mathrm{H}_{2} \mathrm{~S}$ in the HeLa cells. (a) The brighfield image of the HeLa cells treated with Na-H $\mathbf{H}_{2}$ S-ER $(5 \mu \mathrm{M})$; (b) The OP Fluorescence image of a; (c) The merge image of (a and $\left.\mathbf{b}-\mathbf{d}\right)$ The TP Fluorescence image of a; (e) The brighfield image of the HeLa cells treated with Cys (100 $\mu \mathrm{M})$ and Na$\mathbf{H}_{2}$ S-ER $(5 \mu \mathrm{M})$; (f) The OP Fluorescence image of $(\mathbf{e}, \mathbf{g})$ The merge image of (e and $\left.\mathbf{f}, \mathbf{h}\right)$ The TP Fluorescence image of $(\mathbf{e}, \mathbf{i})$ The brighfield image of the HeLa cells treated with Cys $(100 \mu \mathrm{M}), \mathrm{PAG}(200 \mu \mathrm{M})$ and Na-H $\mathbf{H}_{2} \mathrm{~S}-\mathbf{E R}$ $(5 \mu \mathrm{M}) ;(\mathbf{j})$ The OP Fluorescence image of $(\mathbf{i}, \mathbf{k})$ The merge image of $(\mathbf{i}$ and $\mathbf{j}, \mathbf{l})$ The TP Fluorescence image of (i). The OP mode was excitated at $488 \mathrm{~nm}$ and emission collection was from $500-550 \mathrm{~nm}$. The TP mode was excitated at $760 \mathrm{~nm}$ and emission collection was from 500-550 nm. Scale bar: $500 \mu \mathrm{m}$. Scale bar: $20 \mu \mathrm{m}$.

$\left(\lambda_{\mathrm{ex}}=561 \mathrm{~nm} ; \lambda_{\mathrm{em}}=570-620 \mathrm{~nm}\right)$ because of the gathering of ER Tracker. The merged image showed that the well overlap between the green fluorescence and the red fluorescence (Fig. 6c), and the Pearson's colocalization coefficient was 0.91 and the Mander's overlap coefficient was 0.92 (Fig. $6 \mathrm{~d}$ ). The intensity profile of linear regions of interest across HeLa cells in the two channels also varies in close synchrony (Fig. 6e). These data showed that the probe has the prominent property of ER-targeted in the living cells.

Two-photon fluorescence imaging in living tissues. The beneficial results of the living cell researches led us to further apply $\mathbf{N a}-\mathbf{H}_{2} \mathbf{S}$-ER to trace the added $\mathrm{H}_{2} \mathrm{~S}$ in the living liver tissue. Similar to the cell imaging experiments, the liver tissue slices only incubated with $\mathbf{N a - H _ { 2 }} \mathbf{S}$-ER exhibited non-fluorescence (Fig. S13). By contrast, the liver tissue slices treated with the probe and then incubated with added $\mathrm{Na}_{2} \mathrm{~S}$ exhibits strong fluorescent signals was observed up to a depth of $100 \mu \mathrm{m}$ (Fig. 7). Thus, the data showed that the probe is able to detect the addition of $\mathrm{H}_{2} \mathrm{~S}$ in liver tissue slides.

Bio-imaging $\mathrm{H}_{2} \mathrm{~S}$ in living zebrafish. As a model of good vertebrate animals, zebrafish have been widely used for the study of human genetic diseases and developmental biology ${ }^{45,46}$. However, the study of $\mathrm{H}_{2} \mathrm{~S}$ fluorescence imaging using zebrafish as the biological sample is still scarce. Based on the excellent features of $\mathbf{N a}-\mathrm{H}_{2} \mathrm{~S}$-ER, we carried out the fluorescence imaging experiment in the living zebrafish. The zebrafish with feeding $\mathbf{N a}-\mathrm{H}_{2} \mathrm{~S}$-ER were still alive, suggesting that $\mathbf{N a}-\mathrm{H}_{2} \mathrm{~S}$-ER has the potential for biological imaging (Fig. 8a,e). The zebrafish treated only with the probe $\mathbf{N a}-\mathbf{H}_{2} \mathrm{~S}-\mathrm{ER}$ displayed almost no fluorescence (Fig. 8b,d). However, the zebrafish was fed with both the probe and $\mathrm{Na}_{2} \mathrm{~S}$ showed bright fluorescence (Fig. 8f,h), suggesting that $\mathbf{N a}_{2} \mathrm{H}_{2} \mathrm{~S}-\mathbf{E R}$ is capable of imaging added $\mathrm{H}_{2} \mathrm{~S}$ in living zebrafish.

\section{Conclusions}

We had engineered the first ER-targeted two-photon $\mathrm{H}_{2} \mathrm{~S}$ fluorescent probe $\mathbf{N a - H _ { 2 }} \mathbf{S}$-ER. The fluorescence probe contains the fluorescent platform 1,8-naphthalimide and the responding site azide group. When introduced of the $\mathrm{H}_{2} \mathrm{~S}$ to $\mathbf{N a}-\mathrm{H}_{2} \mathrm{~S}$-ER, a large fluorescent emission signal at $545 \mathrm{~nm}$ was observed because of the azide group reduced by $\mathrm{H}_{2} \mathrm{~S}$ to the amine moieties. The probe $\mathbf{N a}-\mathrm{H}_{2} \mathrm{~S}$-ER possessed potential biological imaging value because it has many excellent characteristics, including large fluorescent enhancement signals, high sensitivity and selectivity, 

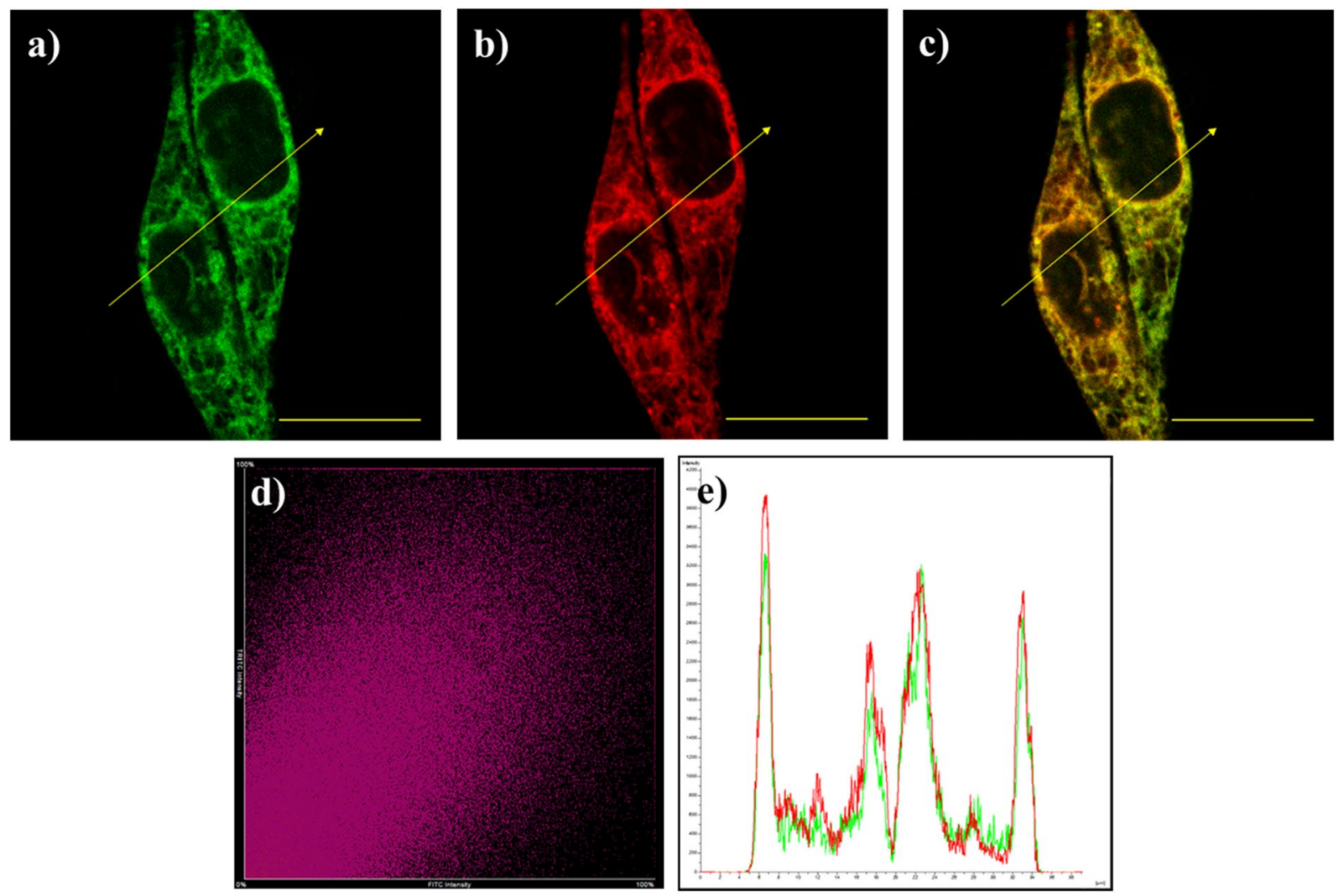

Figure 6. The images of the living HeLa cells co-incubated with the probe $\mathbf{N a}-\mathbf{H}_{2} \mathrm{~S}$-ER $(5 \mu \mathrm{M}), \mathrm{Na}_{2} \mathrm{~S}(50 \mu \mathrm{M})$, and ER-Tracker TM Red. (a) The fluorescence image of the green channel; (b) The fluorescence image of the red channel; (c) The merged image of (a and b,d) Intensity scatter plot of the green and red channels. (e) Intensity profile of linear region of interest across in the HeLa cells co-stained with ER-Tracker Red and green channel of Na-H $\mathbf{H}_{2}$ S-ER. Scale bar: $20 \mu \mathrm{m}$.

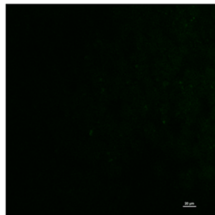

$\mathbf{0} \boldsymbol{\mu m}$

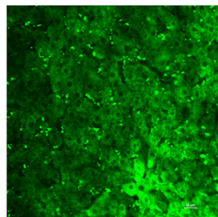

$60 \mu \mathrm{m}$

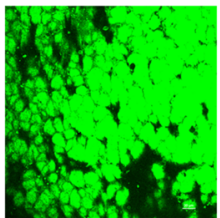

$10 \mu \mathrm{m}$

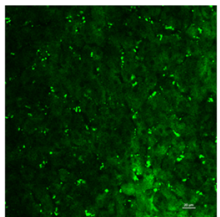

$70 \mu \mathrm{m}$

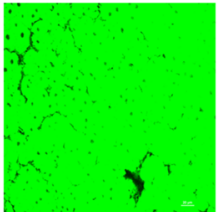

$20 \mu \mathrm{m}$

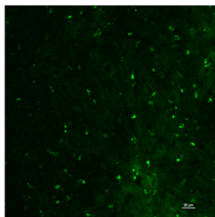

$80 \mu \mathrm{m}$

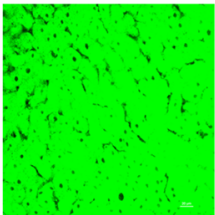

$\mathbf{3 0} \mu \mathrm{m}$

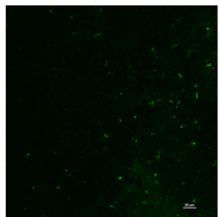

$90 \mu \mathrm{m}$

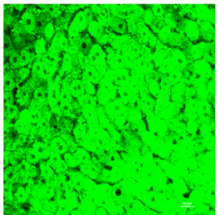

$40 \mu \mathrm{m}$

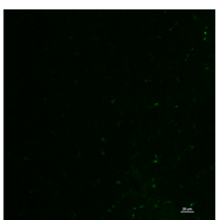

$100 \mu \mathrm{m}$

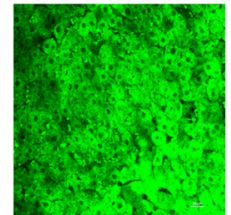

$50 \mu \mathrm{m}$

Figure 7. Fluorescence imaging of added $\mathrm{H}_{2} \mathrm{~S}$ in living liver tissues. The liver tissue slices pretreated with Na$\mathrm{H}_{2}$ S-ER $(30 \mu \mathrm{M})$ for $30 \mathrm{~min}$, and then treated with $\mathrm{Na}_{2} \mathrm{~S}(150 \mu \mathrm{M})$ for another $30 \mathrm{~min}$. Excitation was at $760 \mathrm{~nm}$ and emission collection was from 500-550 nm. Scale bar: $20 \mu \mathrm{m}$.

low cytotoxicity, and working appropriately at the physiological pH. Remarkably, this probe could be applied to monitor the dynamic changes of $\mathrm{H}_{2} \mathrm{~S}$ in ER of the living cells because it possesses the excellent ER-targeted feature. Importantly, the probe has successfully carried out the tissue and zebrafish imaging experiments. We believe that $\mathbf{N a - H _ { 2 }} \mathbf{S}-\mathbf{E R}$ as a powerful molecular tool for monitoring $\mathrm{H}_{2} \mathrm{~S}$ in biological samples.

\section{Methods}

Synthesis of the probe $\mathrm{Na}-\mathrm{H}_{2} \mathrm{~S}-\mathrm{ER}$. The synthesis of compound 2,4 was referred to the previous literature $^{41} .472 \mathrm{mg}$ compound $4(1 \mathrm{mmol})$ and $325 \mathrm{mg}$ sodium azide $(5 \mathrm{mmol})$ were added to $5 \mathrm{~mL}$ of anhydrous 

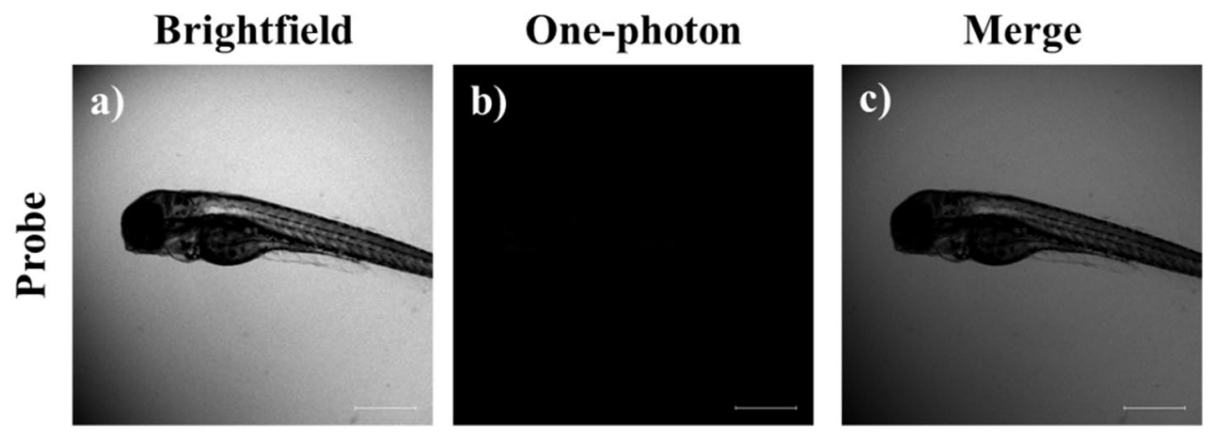

\section{Two-photon}
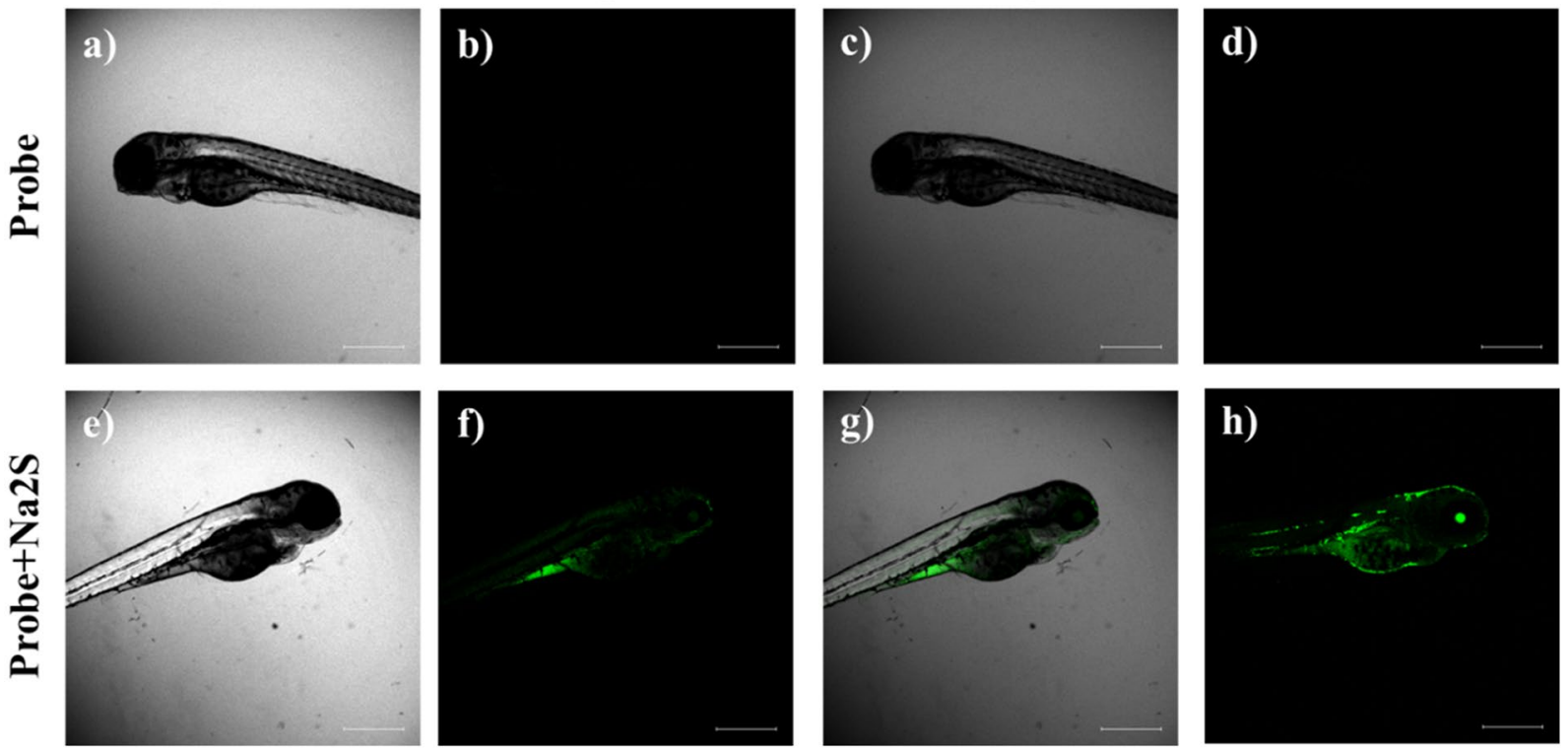

Figure 8. Fluorescence imaging of $\mathrm{H}_{2} \mathrm{~S}$ in living zebrafish. (a) The brighfield image of the zebrafish treated with Na-H $\mathbf{H}_{2} \mathrm{~S}$-ER $(10 \mu \mathrm{M})$; (b) The OP Fluorescence image of $(\mathbf{a}, \mathbf{c})$ The merge image of $(\mathbf{a}$ and $\mathbf{b}, \mathbf{d})$ The TP

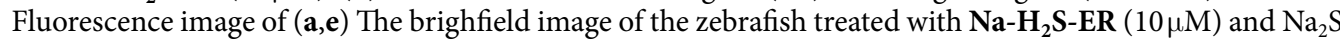
$(50 \mu \mathrm{M}) ;(\mathbf{f})$ The OP Fluorescence image of $(\mathbf{e}, \mathbf{g})$ The merge image of $(\mathbf{e}$ and $\mathbf{f}, \mathbf{h})$ The TP Fluorescence image of e. The OP mode was excitated at $488 \mathrm{~nm}$ and emission collection was from $500-550 \mathrm{~nm}$. The TP mode was excitated at $760 \mathrm{~nm}$ and emission collection was from $500-550 \mathrm{~nm}$. Scale bar: $500 \mu \mathrm{m}$.

DMF. The reaction mixture was heated at $50^{\circ} \mathrm{C}$ overnight under the nitrogen atmosphere. Then $50 \mathrm{~mL} \mathrm{H}_{2} \mathrm{O}$ was added to the reaction system, then extracted with dichloromethane $(20 \mathrm{~mL} \times 3)$. The organic phase was washed with $\mathrm{H}_{2} \mathrm{O}$, dried with $\mathrm{MgSO}_{4}$. The crude product was purified by flash chromatography to afford a yellow solid Na-H $\mathbf{H}_{2}$ S-ER $249 \mathrm{mg}$ with a yield of $57 \% .{ }^{1} \mathrm{H}$ NMR $\left(400 \mathrm{MHz}, \mathrm{DMSO}-d_{6}\right) \delta 8.49(\mathrm{~d}, J=7.2 \mathrm{~Hz}, 1 \mathrm{H}), 8.42(\mathrm{~m}, 2 \mathrm{H})$, $7.86(\mathrm{t}, J=8.0 \mathrm{~Hz}, 1 \mathrm{H}), 7.76(\mathrm{~m}, 2 \mathrm{H}), 7.58(\mathrm{~d}, J=8.0 \mathrm{~Hz}, 2 \mathrm{H}), 7.23 \mathrm{~d}, J=8.0 \mathrm{~Hz}, 2 \mathrm{H}), 4.09(\mathrm{t}, J=8.0 \mathrm{~Hz}, 2 \mathrm{H})$, $3.08(\mathrm{q}, J=5.6 \mathrm{~Hz}, 2 \mathrm{H}), 2.26(\mathrm{~s}, 3 \mathrm{H})^{13}$; C NMR $\left(100 \mathrm{MHz}, \mathrm{DMSO}-d_{6}\right) \delta 163.75,163.30,143.23,142.89,138.14$, $131.96,131.88,129.93,128.68,128.75,127.71,126.80,123.96,122.70,118.72,116.36,21.32$; HR-MS calculated for $\mathrm{C}_{21} \mathrm{H}_{17} \mathrm{~N}_{5} \mathrm{O}_{4} \mathrm{~S}[\mathrm{M}+\mathrm{H}]^{+} \mathrm{m} / \mathrm{z} 436.1074$, found 436.1070 .

Synthesis of the compound Na-ER. A mixture of compound $\mathrm{Na}-\mathrm{H}_{2} \mathrm{~S}-\mathrm{ER} 87 \mathrm{mg}(0.2 \mathrm{mmol})$ was dissolved in $95 \% \mathrm{EtOH}(1 \mathrm{~mL})$, and then $80 \mathrm{mg} \mathrm{Na} 2 \mathrm{~S} \cdot 9 \mathrm{H}_{2} \mathrm{O}(1 \mathrm{mmol})$ was added. The suspension was stirred at room temperature for $1 \mathrm{~h}$. Subsequently, the mixture was concentrated under vacuum, and the resulting residue was purified by silica gel column chromatography $\left(\mathrm{CH}_{2} \mathrm{Cl}_{2} / \mathrm{MeOH}\right.$ as the eluent) to afford $67 \mathrm{mg}$ orange solid of the compound Na-ER with a yield of $83 \% .{ }^{1} \mathrm{H}$ NMR $\left(400 \mathrm{MHz}, \mathrm{DMSO}-d_{6}\right) \delta 8.61(\mathrm{~d}, J=8.0 \mathrm{~Hz}, 1 \mathrm{H}), 8.38(\mathrm{~d}$, $J=6.8 \mathrm{~Hz}, 1 \mathrm{H}), 8.15(\mathrm{~d}, J=8.0 \mathrm{~Hz}, 1 \mathrm{H}), 7.71(\mathrm{t}, J=6.0 \mathrm{~Hz}, 1 \mathrm{H}), 7.64(\mathrm{t}, J=8.0 \mathrm{~Hz}, 1 \mathrm{H}), 7.59(\mathrm{~d}, J=8.0 \mathrm{~Hz}, 2 \mathrm{H})$, $7.46(\mathrm{~s}, 2 \mathrm{H}), 7.23(\mathrm{~d}, J=8.0 \mathrm{~Hz}, 2 \mathrm{H}), 6.83(\mathrm{~d}, J=8.0 \mathrm{~Hz}, 1 \mathrm{H}), 4.07(\mathrm{t}, J=6.4 \mathrm{~Hz}, 2 \mathrm{H}), 3.02(\mathrm{q}, J=6.4 \mathrm{~Hz}, 2 \mathrm{H}), 2.27$ $(\mathrm{s}, 3 \mathrm{H}) ;{ }^{13} \mathrm{C}$ NMR $\left(100 \mathrm{MHz}\right.$, DMSO- $\left.d_{6}\right) \delta 164.32,163.38,153.17,142.86,138.06,134.36,131.38,130.26,129.89$, $129.72,126.84,124.35,122.25,119.81,108.57,108.04,40.79,39.20,21.33$; HR-MS calculated for $\mathrm{C}_{21} \mathrm{H}_{19} \mathrm{~N}_{3} \mathrm{O}_{4} \mathrm{~S}$ $[\mathrm{M}+\mathrm{H}]^{+} \mathrm{m} / \mathrm{z} 410.1169$, found 410.1162 .

Spectral analysis. Unless otherwise noted, all the measurements were made according to the following procedure. The concentration of the probe stock solution was $1.0 \mathrm{mM}$ in DMSO, and the analytes stock solutions were prepared in the ultrapure water at the appropriate concentration. In $5 \mathrm{~mL}$ volumetric flask, the test solution was prepared by placing $25 \mu \mathrm{L}$ probe stock solution and $225 \mu \mathrm{L} \mathrm{DMSO}$, requisite amount of analyte stock solution, then adjusted the final volume to $5 \mathrm{~mL}$ with PBS buffer. The spectrum tests were recorded with a $1 \mathrm{~cm}$ standard quartz cell at room temperature. The absorption spectra were obtained on a Shimadzu UV-2700 Power spectrometer. The photoluminescent spectra were recorded with a HITACHI F4600 fluorescence spectrophotometer. The excitation wavelength was $440 \mathrm{~nm}$, the excitation slit widths were $5 \mathrm{~nm}$, and the emission slit widths were $5 \mathrm{~nm}$.

Cytotoxicity assay. The HeLa cells were seeded up to appropriate density in a 96-well plate. Then the cells were incubated with a series of concentrations of $\mathbf{N a - H _ { 2 }}$ S-ER $(0-20 \mu \mathrm{M})$ at $37^{\circ} \mathrm{C}$. After $24 \mathrm{~h}$, the cells were with PBS buffer, then added MTT $(5 \mathrm{mg} / \mathrm{mL}, 10 \mu \mathrm{L})$ and further incubated for $4 \mathrm{~h}$. After removed the culture medium, DMSO $(100 \mu \mathrm{L})$ was added into the dishes to dissolve the formazan crystal product. Then the absorbance of the solution was measured at $570 \mathrm{~nm}$ by the microplate reader. 
The cell viability $(\%)=\left(\mathrm{OD}_{\text {sample }}-\mathrm{OD}_{\text {blank }}\right) /\left(\mathrm{OD}_{\text {control }}-\mathrm{OD}_{\text {blank }}\right) \times 100 \%$.

$\mathrm{OD}_{\text {sample }}$ denotes the cells incubated with various concentrations of the probe, $\mathrm{OD}_{\text {control }}$ denotes the cells without the probe, $\mathrm{OD}_{\text {blank }}$ denotes the wells containing only the culture medium.

Bio-imaging of exogenous $\mathrm{H}_{2} \mathrm{~S}$ in living HeLa cells. The HeLa cells were seeded up to appropriate density into a $35 \mathrm{~mm}$ glass-bottom culture dishes (Nest). Then the cells further incubated with Na-H $\mathbf{H}_{2} \mathrm{~S}-\mathrm{ER}(5 \mu \mathrm{M})$ for another $20 \mathrm{~min}$ at $37^{\circ} \mathrm{C}$. Then the cells were washed with PBS buffer $(\mathrm{pH}=7.4)$ three times, and the cells incubated with $\mathrm{Na}_{2} \mathrm{~S}(50 \mu \mathrm{M})$ for more $30 \mathrm{~min}$. Finally, the cells were washed three times with PBS buffer. The imaging experiments were recorded through a Nikon A1MP confocal microscopy inverted fluorescence microscopy equipped with a cooled CCD camera. The OP fluorescence emission was collected at 500-550 nm upon excitation at $488 \mathrm{~nm}$ with a femtosecond pulse, and the TP fluorescence emission was collected at $500-550 \mathrm{~nm}$ upon excitation at $760 \mathrm{~nm}$ with a femtosecond pulse.

Bio-imaging of endogenous $\mathrm{H}_{2} \mathrm{~S}$ in living HeLa cells. For the endogenous $\mathrm{H}_{2} \mathrm{~S}$ group, the cells further incubated with Cys $(100 \mu \mathrm{M})$ for another $30 \mathrm{~min}$ at $37^{\circ} \mathrm{C}$, then washed with $\mathrm{PBS}$ three times and further incubated with Na- $\mathrm{H}_{2} \mathrm{~S}-\mathrm{ER}(5 \mu \mathrm{M})$ for another $20 \mathrm{~min}$. For negative control group, the cells incubated with Cys $(100 \mu \mathrm{M})$ and PAG $(200 \mu \mathrm{M})$ for $30 \mathrm{~min}$, then further incubated with $\mathbf{N a - \mathbf { H } _ { 2 }} \mathbf{S}$-ER $(5 \mu \mathrm{M})$ for another 20 min. Finally, the cells were washed three times with PBS buffer. Then the imaging experiments were carried out.

Bio-imaging of added $\mathrm{H}_{2} \mathrm{~S}$ in living tissue. 4 weeks old Kunming mice were purchased from Shandong University Laboratory Animal Centre (Shandong, China). Unless otherwise noted, all procedures for this study were approved by the Animal Ethical Experimentation Committee of Shandong University according to the requirements of the National Act on the use of experimental animals (China). The mice were killed by cervical vertebra dislocation, the liver tissues were cut into about $500 \mu \mathrm{m}$ in size. For the control group, the liver tissue slices treated with $\mathbf{N a}-\mathrm{H}_{2} \mathrm{~S}$-ER $(30 \mu \mathrm{M})$ for $30 \mathrm{~min}$. For the experimental group, the liver tissue slices pretreated with Na- $\mathrm{H}_{2} \mathrm{~S}$-ER $(30 \mu \mathrm{M})$ for $30 \mathrm{~min}$, and then treated with $\mathrm{Na}_{2} \mathrm{~S}(150 \mu \mathrm{M})$ for another $30 \mathrm{~min}$. Then the imaging experiments were carried out.

Bio-imaging of exogenous $\mathrm{H}_{2} \mathrm{~S}$ in living zebrafish. Wild type zebrafish were purchased from the Nanjing EzeRinka Biotechnology Co., Ltd. All procedures for this study were approved by the Animal Ethical Experimentation Committee of Shandong University according to the requirements of the National Act on the use of experimental animals (China). For the control group, the zebrafish were fed with $\mathbf{N a}_{-} \mathbf{H}_{2} \mathrm{~S}-\mathbf{E R}(10 \mu \mathrm{M})$ for $30 \mathrm{~min}$. For the experimental group, the zebrafish were fed with $\mathbf{N a}-\mathbf{H}_{2} \mathbf{S}-\mathbf{E R}(10 \mu \mathrm{M})$ for $30 \mathrm{~min}$, and then treated with $\mathrm{Na}_{2} \mathrm{~S}(50 \mu \mathrm{M})$ for another $30 \mathrm{~min}$. Then the imaging experiments were carried out.

\section{References}

1. Ma, H. et al. The influence of hydrogen sulfide on corrosion of iron under different conditions. Corros. Sci. 42, 1669-1683 (2000).

2. Olas, B. Hydrogen sulfide in signaling pathways. Clin. Chim. Acta. 439, 212-218 (2015).

3. Kamoun, P., Belardinelli, M.-C., Chabli, A., Lallouchi, K. \& Chadefaux-Vekemans, B. Endogenous hydrogen sulfide overproduction in Down syndrome. Am. J. Med. Genet., Part A 116A, 310-311 (2003).

4. Eto, K., Asada, T., Arima, K., Makifuchi, T. \& Kimura, H. Brain hydrogen sulfide is severely decreased in Alzheimer's disease. Biochem. Biophys. Res. Commun. 293, 1485-1488 (2002).

5. Jain, S. K. et al. Low levels of hydrogen sulfide in the blood of diabetes patients and streptozotocin-treated rats causes vascular inflammation? Antioxid. Redox Signaling 12, 1333-1337 (2010).

6. Yang, W., Yang, G., Jia, X., Wu, L. \& Wang, R. Activation of $\mathrm{K}_{\text {ATP }}$ channels by $\mathrm{H}_{2} \mathrm{~S}$ in rat insulin-secreting cells and the underlying mechanisms. J. Physiol. 569, 519-531 (2005).

7. Fiorucci, S. et al. The third gas: $\mathrm{H}_{2} \mathrm{~S}$ regulates perfusion pressure in both the isolated and perfused normal rat liver and in cirrhosis. Hepatology 42, 539-548 (2005).

8. Fukuto, J. M. et al. Small molecule signaling agents: the integrated chemistry and biochemistry of nitrogen oxides, oxides of carbon, dioxygen, hydrogen sulfide, and their derived species. Chem. Res. Toxicol. 25, 769-793 (2012).

9. Pietri, R., Román-Morales, E. \& López-Garriga, J. Hydrogen sulfide and hemeproteins: knowledge and mysteries. Antioxid. Redox Signaling 15, 393-404 (2011).

10. Kabil, O. \& Banerjee, R. Redox biochemistry of hydrogen sulfide. J. Biol. Chem. 285, 21903-21907 (2010).

11. Li, L., Rose, P. \& Moore, P. K. Hydrogen sulfide and cell signaling. Annu. Rev. Pharmacol. Toxicol. 51, 169-187 (2011).

12. Jiménez, D. et al. A new chromo-chemodosimeter selective for sulfide anion. J. Am. Chem. Soc. 125, 9000-9001 (2003).

13. Searcy, D. G. \& Peterson, M. A. Hydrogen sulfide consumption measured at low steady state concentrations using a sulfidostat. Anal. Biochem. 324, 269-275 (2004).

14. Mitchell, T. W., Savage, J. C. \& Gould, D. H. High-performance liquid chromatography detection of sulfide in tissues from sulfidetreated mice. J. Appl. Toxicol. 13, 389-394 (1993).

15. Ishigami, M. et al. A source of hydrogen sulfide and a mechanism of its release in the brain. Antioxid. Redox Signaling 11, 205-214 (2009).

16. Lackowicz, J. R. Principles of fluorescence spectroscopy (ed. Lackowicz, J. R.) (Springer US, 2006)

17. Tang, Y. et al. Development of fluorescent probes based on protection-deprotection of the key functional groups for biological imaging. Chem. Soc. Rev. 44, 5003-5015 (2015).

18. Chen, H., Dong, B., Tang, Y. \& Lin, W. A Unique "Integration" Strategy for the Rational Design of Optically Tunable Near-Infrared Fluorophores. Acc. Chem. Res. 50, 1410-1422 (2017).

19. He, L., Dong, B., Liu, Y. \& Lin, W. Fluorescent chemosensors manipulated by dual/triple interplaying sensing mechanisms. Chem. Soc. Rev. 45, 6449-6461 (2016).

20. Göppert-Mayer, M. Über Elementarakte mit zwei Quantensprüngen. Ann. Phys. 401, 273-294 (1931).

21. Kaiser, W. \& Garrett, C. G. B. Two-photon excitation in $\mathrm{CaF}_{2}$ : $\mathrm{Eu}^{2+}$. Phys. Rev. Lett. 7, 229-231 (1961).

22. Tang, Y., Kong, X., Xu, A., Dong, B. \& Lin, W. Development of a two-photon fluorescent probe for imaging of endogenous formaldehyde in living tissues. Angew. Chem., Int. Ed. 55, 3356-3359 (2016). 
23. Quinn, P., Griffiths, G. \& Warren, G. Density of newly synthesized plasma membrane proteins in intracellular membranes II. Biochemical studies. J. Cell Biol. 98, 2142-2147 (1984).

24. Baumann, O. \& Walz, B. Endoplasmic reticulum of animal cells and its organization into structural and functional domains. Int. Rev. Cytol. 205, 149-214 (2001).

25. Peretti, D., Dahan, N., Shimoni, E., Hirschberg, K. \& Lev, S. Coordinated Lipid Transfer between the Endoplasmic Reticulum and the Golgi Complex Requires the VAP Proteins and Is Essential for Golgi-mediated Transport. Mol. Biol. Cell 19, 3871-3884 (2008).

26. Pichler, H. et al. A subfraction of the yeast endoplasmic reticulum associates with the plasma membrane and has a high capacity to synthesize lipids. Eur. J. Biochem. 268, 2351-2361 (2001).

27. Friedman, J. R. \& Voeltz, G. K. The ER in 3D: a multifunctional dynamic membrane network. Trends Cell Biol. 21, 709-717 (2011).

28. Lin, V. S., Chen, W., Xian, M. \& Chang, C. J. Chemical probes for molecular imaging and detection of hydrogen sulfide and reactive sulfur species in biological systems. Chem. Soc. Rev. 44, 4596-4618 (2015).

29. Hai, Z., Bao, Y., Miao, Q., Yi, X. \& Liang, G. Pyridine-biquinoline-metal complexes for sensing pyrophosphate and hydrogen sulfide in aqueous buffer and in cells. Anal. Chem. 87, 2678-2684 (2015).

30. Singha, S. et al. Toward a selective, sensitive, fast-responsive, and biocompatible two-Photon probe for hydrogen sulfide in live cells. Anal. Chem. 87, 1188-1195 (2015).

31. Wang, S. et al. A fluorescent chemodosimeter for live-cell monitoring of aqueous sulfides. Anal. Chem. 88, 1434-1439 (2016).

32. Li, H. D. et al. A fluorescent probe for $\mathrm{H}_{2} \mathrm{~S}$ in vivo with fast response and high sensitivity. Chem. Commun. 51, 16225-16228 (2015).

33. Cao, J. et al. Chemiluminescent probes for imaging $\mathrm{H}_{2} \mathrm{~S}$ in living animals. Chem. Sci. 6, 1979-1985 (2015).

34. Kim, Y. et al. Exceptional time response, stability and selectivity in doubly-activated phenyl selenium-based glutathione-selective platform. Chem. Sci. 6, 5435-5439 (2015).

35. Hammers, M. D. et al. A bright fluorescent probe for $\mathrm{H}_{2} \mathrm{~S}$ enables analyte-responsive, 3D imaging in live zebrafish using light sheet fluorescence microscopy. J. Am. Chem. Soc. 137, 10216-10223 (2015).

36. Pak, Y. L. et al. Mitochondria-targeted reaction-based fluorescent probe for hydrogen sulfide. Anal. Chem. 88, 5476-5481 (2016).

37. Karakuş, E., Üçüncü, M. \& Emrullahoğlu, M. Electrophilic cyanate as a recognition motif for reactive sulfur species: selective fluorescence detection of $\mathrm{H}_{2} \mathrm{~S}$. Anal. Chem. 88, 1039-1043 (2016).

38. Gong, D. et al. A phenylselenium-substituted BODIPY fluorescent turn-off probe for fluorescence imaging of hydrogen sulfide in living cells. Anal. Chem. 89, 1801-1807 (2017).

39. Lv, J.et al. Enhanced response speed and selectivity of fluorescein-based $\mathrm{H}_{2} \mathrm{~S}$ probe via the cleavage of nitrobenzene sulfonyl ester assisted by ortho aldehyde groups. Biosens. Bioelectron. 87, 96-100 (2017).

40. Xiao, H. et al. Simultaneous fluorescence imaging of hydrogen peroxide in mitochondria and endoplasmic reticulum during apoptosis. Chem. Sci. 7, 6153-6159 (2016).

41. Tang, Y. et al. A turn-on fluorescent probe for endogenous formaldehyde in the endoplasmic reticulum of living cells. Methods Appl. Fluoresc. 5, 024005 (2017).

42. Xiao, H. et al. Ratiometric photoacoustic imaging of endoplasmic reticulum polarity in injured liver tissues of diabetic mice. Chem. Sci., https://doi.org/10.1039/C7SC02330H (2017).

43. Xu, S. et al. Visualization of endoplasmic reticulum aminopeptidase 1 under different redox conditions with a two-photon fluorescent probe. Anal. Chem. 89, 7641-7648 (2017).

44. Sun, Q. et al. Structural basis for the inhibition mechanism of human cystathionine $\gamma$-Lyase, an enzyme responsible for the production of $\mathrm{H}_{2}$ S. J. Biol. Chem. 284, 3076-3085 (2009).

45. Poss, K. D., Wilson, L. G. \& Keating, M. T. Heart regeneration in zebrafish. Science 298, 2188-2190 (2002).

46. Curado, S., Stainier, D. Y. R. \& Anderson, R. M. Nitroreductase-mediated cell/tissue ablation in zebrafish: a spatially and temporally controlled ablation method with applications in developmental and regeneration studies. Nat. Protoc. 3, 948-954 (2008).

\section{Acknowledgements}

This work was financially supported by NSFC (21472067, 21672083), Taishan Scholar Foundation (TS201511041), and the startup fund of University of Jinan (309-10004).

\section{Author Contributions}

W. Lin and Y. Tang conceived the idea and directed the work. Y. Tang and A. Xu designed the experiments and performed the organic synthesis. Y. Tang, G. Xu and S. Gao performed the spectral measurements. Y. Tang and Y. Ma performed the bioimaging experiments. All authors contributed to data analysis, manuscript writing and participated in research discussions.

\section{Additional Information}

Supplementary information accompanies this paper at https://doi.org/10.1038/s41598-017-13325-z.

Competing Interests: The authors declare that they have no competing interests.

Publisher's note: Springer Nature remains neutral with regard to jurisdictional claims in published maps and institutional affiliations.

(c) (i) Open Access This article is licensed under a Creative Commons Attribution 4.0 International

License, which permits use, sharing, adaptation, distribution and reproduction in any medium or format, as long as you give appropriate credit to the original author(s) and the source, provide a link to the Creative Commons license, and indicate if changes were made. The images or other third party material in this article are included in the article's Creative Commons license, unless indicated otherwise in a credit line to the material. If material is not included in the article's Creative Commons license and your intended use is not permitted by statutory regulation or exceeds the permitted use, you will need to obtain permission directly from the copyright holder. To view a copy of this license, visit http://creativecommons.org/licenses/by/4.0/.

(c) The Author(s) 2017 